\title{
EFFECT OF HYOSCIN N-BUTYL BROMIDE ON GASTRIC ULCERATION INDUCED BY INDOMETHACIN AND RESTRAINT STRESS, AND ON GASTRIC SECRETION IN ADULT MALE ALBINO RATS
}

\author{
By
Mohamed Samy El-Ficky, Mohammed Abulhasan Sayed-Ahmed Zoair, Sayed Abd-El Reheim Sayed* and Wael Ahmed Khattab

Departments of Medical Physiology and Pathology*, Al-Azhar Faculty of Medicine

\begin{abstract}
Background: Hyoscine N-butylbromide (Buscopan) is clinically used as an anticholinergic antispasmodic for the treatment of abdominal cramping or visceral pain associated with cramps.

Objectives: we aimed to study the effect of pretreatment by a single injection of various doses of Hyoscin Nbutylbromide (HBB) $(1 \mathrm{mg} / \mathrm{Kg}, 2.5 \mathrm{mg} / \mathrm{Kg}$ and $5 \mathrm{mg} / \mathrm{Kg})$, on changes in gastric contents in pyloric ligated rats receiving indomethacin in a dose of $100 \mathrm{mg} / \mathrm{Kg}$ i.p, and on gastric ulcer formation induced in rats by the same dose of indomethacin and subjected to restraint stress.

Materials and Methods: This study was conducted on 60 adult male albino rats, divided into two equal categories, which were further divided into five equal subgroups.

Results: Administration of $\mathrm{HBB}$ in doses of $1 \mathrm{mg} / \mathrm{Kg}$ (i.p) to rats subjected to restraint stress and indomethacin administration in a dose of $100 \mathrm{mg} / \mathrm{kg}$ led to insignificant decrease in the gastric ulcer index relative to the group received indomethacin and subjected to restraint stress with a protection ratio of (3\%). Administration of $\mathrm{HBB}$ in doses of $2.5 \mathrm{mg} / \mathrm{Kg}$ and $5 \mathrm{mg} / \mathrm{Kg}$ (i.p) to rats subjected to restraint stress and indomethacin administration in a dose of $100 \mathrm{mg} / \mathrm{kg}$ led to a significant decrease in the gastric ulcer index relative the group received indomethacin and subjected to restraint stress with a protection ratio of $60.46 \%$ and $66.41 \%$ respectively. Administration of $\mathrm{HBB}$ in doses of $1 \mathrm{mg} / \mathrm{Kg}, 2.5 \mathrm{mg} / \mathrm{Kg}$ and $5 \mathrm{mg} / \mathrm{Kg}$ (i.p) to pyloric-ligated rats led to a significant decrease in gastric juice volume, acid concentration and the total acid output compared to the group receiving indomethacin.

Conclusion: Intraperitoneal administration of $\mathrm{HBB}$ in doses of $1 \mathrm{mg} / \mathrm{Kg}, 2.5 \mathrm{mg} / \mathrm{Kg}$ and $5 \mathrm{mg} / \mathrm{Kg}$ to rats in a dose-dependent manner led to a prophylactic effect against stress induced gastric ulcers, with a protection ratio of $3 \%, 60.46 \%$ and $66.41 \%$ respectively.
\end{abstract}

Key words: HBB, gastric secretion, gastric ulcer, restraint stress, Indomethacin. 


\section{Mohamed Samy El-Ficky et al.}

\section{INTRODUCTION}

Hyoscine N-butylbromide (HBB) is a quaternary ammonium compound, which blocks the action of acetylcholine at parasympathetic sites (both muscarinic and nicotinic receptors) in smooth muscle, and in secretory glands. It causes decreased motility of the gastrointestinal tract. So, it is useful in the treatment of abdominal cramping or visceral pain associated with cramps (Zhang et al., 2016), allowing the system to reset normal peristaltic gut activity, i.e. sympatholytic effect in patients and healthy volunteers (Krueger et al., 2013). It is unable to cross the blood brain barrier to exert central nervous system effects (Lacy et al., 2013). It also retains its polar nature regardless of surrounding $\mathrm{pH}$, and is, therefore, poorly absorbed $(8 \%)$ after oral intake with a systemic bioavailability less than $1 \%$. Although orally administered $\mathrm{HBB}$ is excreted in both the feces and in the urine, the metabolites excreted via the renal route bind poorly to the muscarinic receptors and are, therefore, not considered active there (Samuels et al., 2009).

Successful widespread use as well as accumulation of scientific evidence of oral HBB has paved the way for pharmaceutical reformulation, indication expansion, and generic availability as well as rescheduling from prescription only to over-the-counter status in many countries (Whittaker, 2010). Oral HBB is indicated for the relief of smooth muscle spasm of both the gastrointestinal and genitourinary systems (Ruepert et al., 2011), while the parenteral ampoules for injection are indicated for the relief of acute genitourinary or gastrointestinal spasm e.g., renal or biliary colic (Tytgat, 2008). From a pharmacological perspective, it is gratifying that hyoscine, under the wings of N-butylbromide, has emerged from its deadly shadow to become a useful therapy for functional cramping abdominal pain, a condition estimated to affect $30 \%$ of the Western adult population (Lacy et al., 2013).

Indomethacin is an indol derivative, non-steroidal, anti-inflammatory drug with anti-inflammatory, analgesic, and antipyretic effects. Indomethacin is the first-choice drug to produce an experimental ulcer model as a result of having a higher ulcerogenic potential than other non-steroidal anti-inflammatory drugs (NSAIDs). Some antiulcer drugs have been shown to inhibit indomethacininduced ulcers without affecting acid and mucus secretion or oxidant parameters, as well as to inhibit the production of protective factors like COX-1, PGE2, and bicarbonate, and to reduce antioxidant parameters (Suleyman et al., 2010).

The aim of the present work was to study the effect of single injection of various doses of Hyoscin $\mathrm{N}$-butylbromide (HBB) $(1 \mathrm{mg} / \mathrm{Kg}, 2.5 \mathrm{mg} / \mathrm{Kg}$ and $5 \mathrm{mg} / \mathrm{Kg})$ on gastric contents (volume and acidity), as well as on gastric ulcer formation induced in rats by indomethacin and subjected to restraint stress.

\section{MATERIALS AND METHODS}

\section{Animals:}

Sixty adult male Sprague - Dawley rat weighing 120-170 g were purchased form Abu-Rawash Animal House (Giza, Egypt). Animals were given fed with standard commercial rat chow and water. They were left to accommodate for one 
week and kept on normal dark/light cycle in partially humid and well - aerated room, at room temperature $(22 \pm 20 \mathrm{C})$. Rats were kept in cages $(20 \times 32 \times 20 \mathrm{~cm}$ for every four rats).

The rats were fasted for $24 \mathrm{hr}$ prior to the induction of the gastric ulcers in wide meshed cages to minimize coprophagia. The animals had free access to water except for the last hour before the experiment. All the experiments were performed during the same time of the day to avoid variations due to diurnal rhythms of putative regulators of gastric functions.

Immediately after indomethacin injection $(100 \mathrm{mg} / \mathrm{kg})$ (i.p) according to the method of Berenguer et al. (2006), rats were restrained for $24 \mathrm{hr}$. according to the method of Anchkov and Zovodyskaya (1968) to increase the vulnerability of the rat gastric mucosa to the ulcerogenic effect of indomethacin. Rats were divided into two main equal groups:

A-The first group (group A) was used for the study of the effect of HBB on gastric ulcers induced by immobilization for $24 \mathrm{hr}$ and indomethacin administration in a dose of $100 \mathrm{mg} / \mathrm{Kg}$. This group was further subdivided into 5 equal groups:

Group AI received saline i.p. in a dose of $1 \mathrm{~mL} / \mathrm{rat}$.

Group AII received indomethacin in a dose of $100 \mathrm{mg} / \mathrm{Kg}$ i.p immediately before the immobilization stress.

Group AIII received HBB i.p. in a dose of $1 \mathrm{mg} / \mathrm{Kg}, 1 / 2 \mathrm{~h}$ before immobilization stress and indomethacin administration (i.p).

Group AIV received HBB i.p. in a dose of $2.5 \mathrm{mg} / \mathrm{Kg}, \quad 1 / 2 \mathrm{~h}$ before the immobilization stress and indomethacin administration (i.p).

Group AV received HBB i.p. in a dose of $5 \mathrm{mg} / \mathrm{Kg}, \quad 1 / 2 \mathrm{~h}$ before the immobilization stress and indomethacin administration (i.p).

B-The Second group (group B) was fasted for $48 \mathrm{hr}$ in a wide meshed bottom cages used for the study of the effect of HBB on gastric secretion in pyloric ligated rats received indomethacin i.p in a dose $(100 \mathrm{mg} / \mathrm{Kg})$, which was further subdivided into 5 equal groups:

Group BI received saline i.p. in a dose of $1 \mathrm{~mL} /$ rat immediately before pyloric ligation.

Group BII received indomethacin in a dose of $100 \mathrm{mg} / \mathrm{Kg}$ (i.p) immediately before pyloric ligation.

Group BIII received HBB i.p. in a dose of $1 \mathrm{mg} / \mathrm{Kg}, 1 / 2 \mathrm{~h}$ before indomethacin administration (i.p) and pyloric ligation.

Group BIV received HBB i.p. in a dose of $2.5 \mathrm{mg} / \mathrm{Kg}, 1 / 2 \mathrm{~h}$ before indomethacin administration (i.p) and pyloric ligation.

Group BV received HBB i.p. in a dose of $5 \mathrm{mg} / \mathrm{Kg}, 1 / 2 \mathrm{~h}$ before indomethacin administration (i.p) and pyloric ligation.

\section{Drugs and chemicals:}

- Saline: Physiological saline $(0.9 \% \mathrm{NaCl})$ was obtained from a local pharmacy.

- Indomethacin ampoules (50mg/2mL) were obtained from El-Nile Company, Egypt.

- Hyoscine N-butylbromide (HBB) ampoules $(20 \mathrm{mg} / \mathrm{mL})$ : were obtained from Chemical Industries Development (CID) Giza, Egypt. 


\section{Mohamed Samy El-Ficky et al.}

\section{Method of induction of gastric ulcer by} restraint stress: The animals were immobilized in supine position for $24 \mathrm{hr}$, after $24 \mathrm{hr}$ fasting, by fixing the four limbs at the four corners of the wooden board $(35 \mathrm{~cm} \times 45 \mathrm{~cm})$. Immobilization was sufficient to prevent the animal from turning and wedging itself, without hindrance of respiration. The mechanism of induction of gastric lesion by the use of the immobilization technique was according to (Anchkov and Zovodskoya, 1968). After $24 \mathrm{hr}$, animals were sacrificed, and abdominal cavity was opened, and the stomach was quickly removed. It was opened along the greater curvature. The mucosa was washed with normal saline, pinned out on cork, and was inspected for the presence of ulceration and hemorrhage by the naked eye, and with the help of a binocular magnifying lens (2X). Lesions were defined as erosions of the gastric mucosa, which may be linear along the regular folds or punched out, and their bases were red or black.

Method of collection and analysis of gastric secretion: Gastric juice was collected according to the technique of (Shay et al., 1954). Rats were kept individually in separate wide meshed cages to insure immediate passage of feces from the cage and to prevent coprophagia.

The animals were starved for 48 hours before the experiment to ensure emptying of the stomach, and water was permitted ad libitum. Fasting of animals was started in early morning. The animals were weighed immediately before fasting and at the end of $48 \mathrm{hrs}$ of starvation. One hour before the experiment, water was removed from the cages.

Operative procedures: Under light isoflurine anesthesia, a midline incision was made extending from the xiphoid process downwards for $2 \mathrm{~cm}$. The duodenum was exposed and the pyloriduodenal junction was picked up gently by a curved probe. A pyloric ligature was made by silk suture. The abdominal wound was then closed with interrupted sutures. The abdominal wound was cleaned thoroughly with physiological saline, dried and covered with collodion solution.

Dehydration before operation was avoided as it affects the rate of gastric secretion. Three hours later, rats were anesthetized again with isoflurine, abdomen was opened, the esophagus was ligated, and the stomach was removed and washed with saline. The stomach was then opened at the greater curvature, and gastric juice was drained into a graduated centrifuge test tube through a funnel.

Analysis of the gastric juice contents: Gastric juice of each stomach was analyzed individually, drained into a graduated centrifuge test tube, and centrifuged at 3000 (rpm) for 15 minutes. The clear supernatant fluid was estimated and analyzed for:

1. The volume of gastric juice by using graduated test tube.

2. Titritable acidity was measured colorimetrically by determining the number of millimeters of $0.01 \mathrm{~N}$ $\mathrm{NaOH}$ required for neutralizing 100 $\mathrm{mL}$ of gastric juice. A given volume of gastric juice $(0.2 \mathrm{~mL})$ was titrated to $\mathrm{pH} 7.0$ against $0.01 \mathrm{~N} \mathrm{NaOH}$ 
using phenol red as an indicator (Grossman, 1963).

3. The total titritable acid output (microequvilant/3h) was calculated by multiplying the volume of gastric juice (in $\mathrm{mL}$ ) by the titritable acidity (in $\mathrm{mEq} / \mathrm{L}$ ) divided by 1000 (Brodie \& Hook, 1971 and Okabe et al., 1975), and it was expressed as $\mu \mathrm{Eq} / 3$ hours.

Estimation of the ulcer index: The total lengths of gastric lesions per stomach (expressed in $\mathrm{mm}$ ) were judged by two independent researchers blinded to the protocol of (Jansson et al., 2007). The sum of the lengths of gastric ulcers (in $\mathrm{mm})$ in the group was used as an ulcer index according to the method of (Kasuya et al., 1978).

The preventive index (\%) was estimated according to the method of (Cuparencu and Sandor, 1977).

Preventive index $(\%)=$

$\frac{\text { Meanulcer inder(control) }- \text { Mean ulcer inder (treated] }}{\text { Meanulcer inder (control) }} \times 100$
The preventive index (the protection ratio) was considered to be significant if its percentage exceeded $33 \%$.

Histopathological examination: The specimens were stained with hematoxylin and eosin for examination of the stomach by light microscope according to the method of (Drury and Wallington, 1980).

Statistical analysis: One way ANOVA (Analysis Of Variance) test was used to do the following: Calculation of the descriptive statistics in studied groups (means \pm standard deviations). Detection of any significant difference between different groups and between different samples. Performing multiple comparisons between each group and another and each sample and another by using the "Post Hoc LSD" multiple comparison tests. The computer program SPSS version "17" was used to perform ANOVA test. $\mathrm{P}$ value $<0.05$ was considered significant.

\section{RESULTS}

Studies on gastric ulcer:

A- Effect of i.p administration of various doses of Hyoscine $\mathrm{N}$ butylbromide (HBB) (1mg/kg, $2.5 \mathrm{mg} / \mathrm{kg}$, and $5 \mathrm{mg} / \mathrm{kg}$ ) on gastric ulcers induced by the synergistic effect of i.p administration of $100 \mathrm{mg} / \mathrm{kg}$ indomethacin and restraint stress for $24 \mathrm{hr}$ in adult male albino rats (Table 1).
1. Effect of saline administration in a dose $1 \mathrm{~mL}$ (i.p) on the gastric mucosa of the rats (control group).

The total of lengths of ulcers in mms per group $=0 \mathrm{mms}$

The mean lengths of ulcers in mms per group $=0 \mathrm{mms}$

2. Effect of indomethacin administration (i.p) in a dose of $\mathbf{1 0 0}$ $\mathrm{mg} / \mathrm{Kg}$ on the gastric mucosa of rats subjected to immobilization stress. 


\section{Mohamed Samy El-Ficky et al.}

The total lengths of ulcers in mms per group $=134 \mathrm{mms}$.

The mean lengths of ulcers in mms per group $=134 / 6=22.33$.

3. Effect of HBB administration (i.p) in a dose of $1 \mathrm{mg} / \mathrm{Kg}, 1 / 2 \quad \mathrm{~h}$ before immobilization stress and indomethacin administration (i.p) on the gastric mucosa of rats.

The total lengths of ulcers in mms per group $=130 \mathrm{mms}$.

The mean lengths of ulcers in mms per group $=130 / 6=21.67$.

The preventive index

$$
=\frac{22.33-21.67}{22} .33=3 \% \text {. }
$$

4. Effect of HBB administration (i.p) in a dose of $2.5 \mathrm{mg} / \mathrm{Kg}, 1 / 2 \mathrm{~h}$ before immobilization stress and indomethacin administration (i.p) on the gastric mucosa of rats.
The total lengths of ulcers in mms per group $=53 \mathrm{mms}$.

The mean lengths of ulcers in mms per group $=8.83 \mathrm{mms}$

The preventive index = $22.33-8.83$

$22.33=60.46 \%$

5. Effect of HBB administration (i.p) in a dose of $5 \mathrm{mg} / \mathrm{Kg}, \quad 1 / 2 \quad h$ before immobilization stress and indomethacin administration (i.p) on the gastric mucosa of rats.

The total lengths of ulcers in mms per group $=45 \mathrm{mms}$.

The mean lengths of ulcers in mms per group $=7.5 \mathrm{mms}$

The preventive index = $\frac{22.33-7.50}{22} .33=66.41 \%$

Table (1): Effect of i.p administration of various doses of Hyoscine N-butylbromide (HBB) $(1 \mathrm{mg} / \mathrm{kg}, 2.5 \mathrm{mg} / \mathrm{kg}$, and $5 \mathrm{mg} / \mathrm{kg})$ on gastric ulcers induced by the synergistic effect of i.p administration of $100 \mathrm{mg} / \mathrm{kg}$ indomethacin and restraint stress for $24 \mathrm{hr}$ in male albino rats

\begin{tabular}{|l|c|c|c|}
\hline \multirow{2}{*}{ Parameters } & \multicolumn{2}{|c|}{ Ulcer index } & \multirow{2}{*}{$\begin{array}{c}\text { The Mean } \\
\text { Groups } \\
\text { (n=6) }\end{array}$} \\
\cline { 2 - 3 } & $\begin{array}{c}\text { The sum of the } \\
\text { lengths of ulcers in } \\
\text { mms / group } \\
\text { (Total) }\end{array}$ & $\begin{array}{c}\text { Thentive } \\
\text { lengths of ulcers } \\
\text { in mms / group } \\
\text { index (\%) }\end{array}$ & \\
\hline Group (AI) & 0 & 0 & - \\
\hline Group (AII) & 134 & 22.33 & - \\
\hline Group (AIII) & 130 & 21.67 & $3 \%$ \\
\hline Group (AVI) & 53 & 8.83 & $60.46 \%$ \\
\hline Group (AV) & 45 & 7.50 & $66.41 \%$ \\
\hline
\end{tabular}

$-n=$ Number of rats in each group.

-Group AII, was compared to the control group AI.

-Groups AIII, AIV and AV were compared to groups AII. 
Group AI received neither Indomethacin (Indo) nor subjected to Restraint Stress (R.S).

Group AII received i.p Indomethacin (Indo) in a dose of $100 \mathrm{mg} / \mathrm{Kg}$ and subjected to Restraint Stress for $24 \mathrm{hrs}$.

Group AIII received i.p (HBB) in a dose of $1 \mathrm{mg} / \mathrm{Kg}$ before i.p (Indo) in a dose of $100 \mathrm{mg} / \mathrm{Kg}+\mathrm{R} . \mathrm{S}$ for $24 \mathrm{hrs}$.

Group AVI received i.p (HBB) in a dose of $2.5 \mathrm{mg} / \mathrm{Kg}$ before i.p (Indo) in a dose of $100 \mathrm{mg} / \mathrm{Kg}+\mathrm{R} . \mathrm{S}$ for $24 \mathrm{hrs}$.

Group AV received i.p (HBB) in a dose of $5 \mathrm{mg} / \mathrm{Kg}$ before i.p (Indo) in a dose of $100 \mathrm{mg} / \mathrm{Kg}+\mathrm{R} . \mathrm{S}$ for $24 \mathrm{hrs}$.

B- Histopathological examination: Examination of the rat gastric mucosa :

Effect of i.p administration of various doses of Hyoscine N-butylbromide (HBB) $(1 \mathrm{mg} / \mathrm{kg}, 2.5 \mathrm{mg} / \mathrm{kg}$, and $5 \mathrm{mg} / \mathrm{kg})$ on the gastric mucosa of rats subjected to restraint stress and immediately received indomethacin in a dose of $100 \mathrm{mg} / \mathrm{kg}$ (i.p).

The gastric mucosa in rats subjected to restraint stress and immediately received indomethacin in a dose of $100 \mathrm{mg} / \mathrm{kg}$ (i.p) showed by naked eye examination multiple ulcers in each corpus of the stomach, and by light microscope showed deep ulcers reaching the submucosal layer, complete loss of superficial mucus layer, marked submucosal oedema, loss of architecture of the oxyntic cells and marked congested mucosal blood vessels (Figures 1, 2\& 3).

The gastric mucosa in rats received Hyoscine N-butylbromide in a dose of $1 \mathrm{mg} / \mathrm{kg}$ (i.p) $1 / 2 \mathrm{hr}$ before restraint stress and immediate indomethacin administration in a dose of $100 \mathrm{mg} / \mathrm{kg}$ (i.p) showed by naked eye examination multiple ulcers in each corpus of the stomach, and by light microscope showed partial preservation of the mucus layer, deep mucosal ulcer not penetrating the submucosa, moderate submucosal oedema, scattered parietal cells and marked dilated congested submucosal blood vessels (Figures 4, 5\& 6).

The gastric mucosa in rats received Hyoscine N-butylbromide in a dose of $2.5 \mathrm{mg} / \mathrm{kg}$ (i.p) $1 / 2 \mathrm{hr}$ before restraint stress and immediate indomethacin administration in a dose of $100 \mathrm{mg} / \mathrm{kg}$ (i.p) showed by naked eye examination multiple ulcers in each corpus of the stomach, and by light microscope showed deep ulcers involving the whole mucosal thickness and lined by granulation tissue, mild submucosal oedema and partial loss of superficial mucus layer (Figures 7, 8\& 9).

The gastric mucosa in rats received Hyoscine N-butylbromide in a dose of $5 \mathrm{mg} / \mathrm{kg}$ (i.p) $1 / 2 \mathrm{hr}$ before restraint stress and immediate indomethacin administration in a dose of $100 \mathrm{mg} / \mathrm{kg}$ (i.p) showed by naked eye examination very few superficial gastric mucosal ulcers, and by light microscope showed gastric mucosal ulcers not penetrating the deep epithelial layer, preservation of the mucus layer and very mild submucosal edema (Figures 10, 11\& 12). 


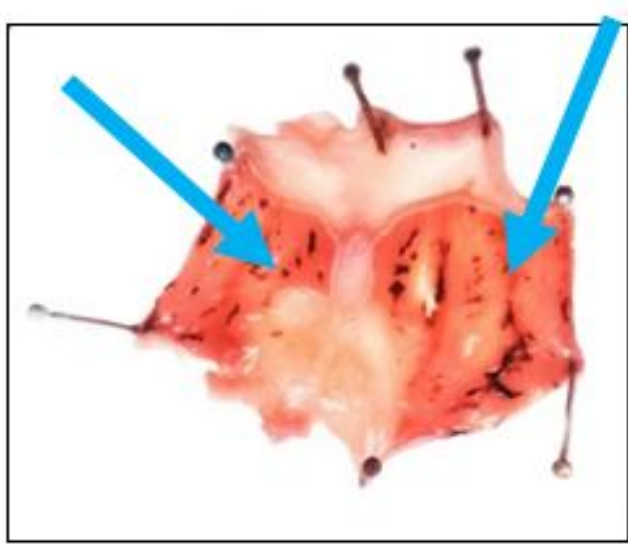

Fig. (1)

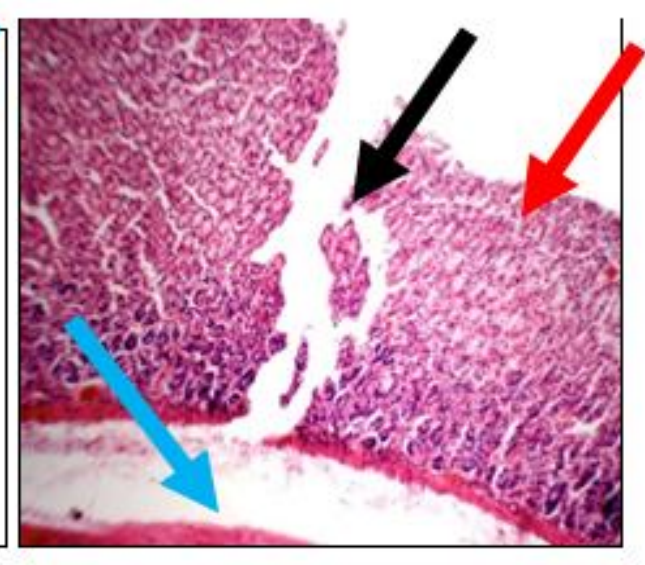

Fig. (2)

Figure (1): Rats subjected to restraint stress and immediately received indomethacin in a dose of $100 \mathrm{mg} / \mathrm{kg}$ (i.p). Naked eye examination showed multiple ulcers in each corpus of the stomach (blue arrows).

Figure (2): Rats subjected to restraint stress and immediately received indomethacin in a dose of $100 \mathrm{mg} / \mathrm{kg}$ (i.p). Histopathological examination showed (i) Deep ulcers reaching the submucosal layer (black arrow), (ii) Complete loss of superficial mucus layer (red arrow),(iii) Marked submucosal oedema (blue arrow) (H\&E x235).
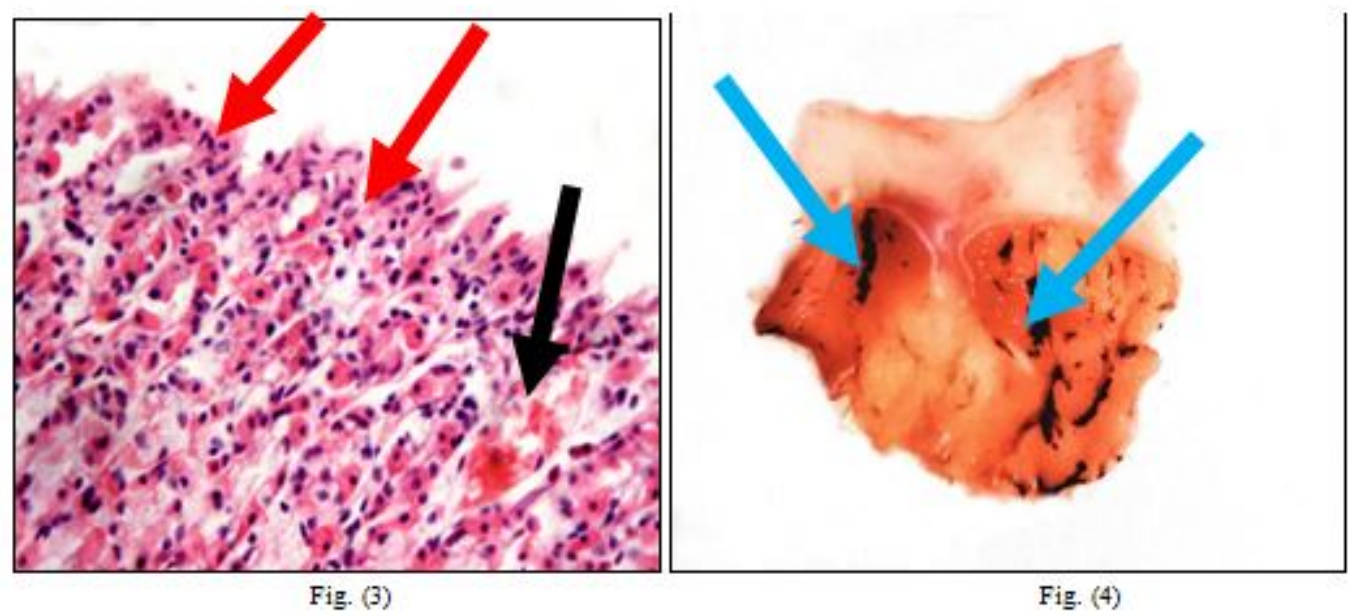

Figure (3): Rats subjected to restraint stress and immediately received indomethacin in a dose of $100 \mathrm{mg} / \mathrm{kg}$ (i.p). Histopathological examination showed: (i) Loss of architecture of the oxyntic cells (red arrows), (ii) Marked congested mucosal blood vessels (black arrow) (H\&E x360).

Figure (4): Rats received Hyoscine N-butylbromide in a dose of $1 \mathrm{mg} / \mathrm{kg}$ (i.p) $1 / 2 \mathrm{hr}$ before restraint stress and immediate indomethacin administration in a dose of $100 \mathrm{mg} / \mathrm{kg}$ (i.p). Naked eye examination showed multiple ulcers in each corpus of the stomach (blue arrows). 


\section{EFFECT OF HYOSCIN N-BUTYL BROMIDE}

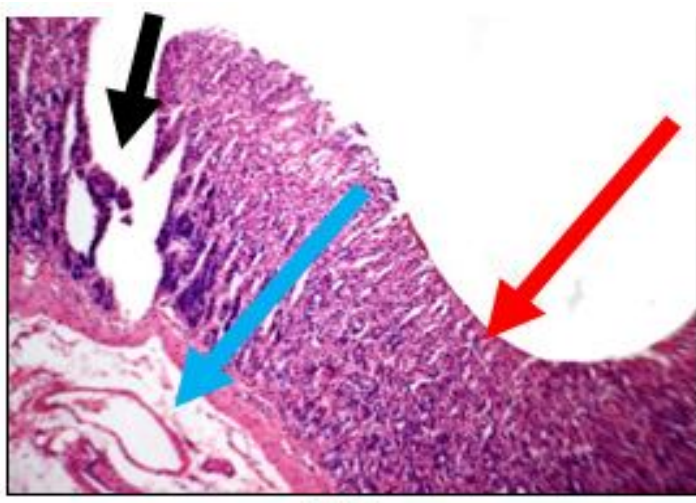

Fig. (5)

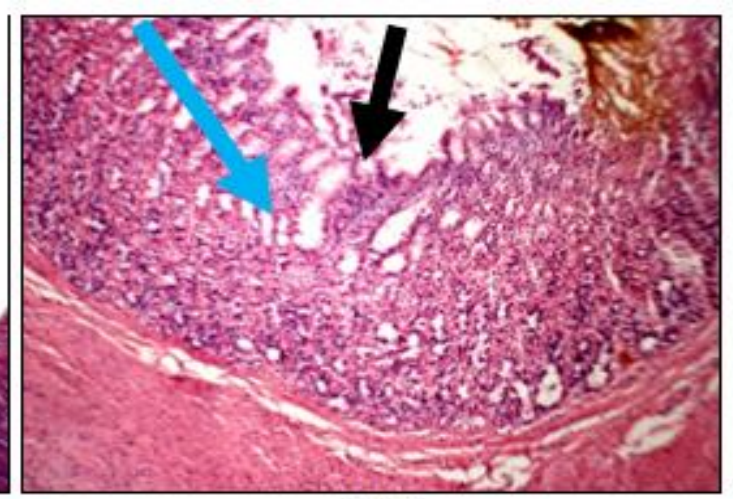

Fig. (6)

Figure (5): Rats received Hyoscine N-butylbromide in a dose of $1 \mathrm{mg} / \mathrm{kg}$ (i.p) $1 / 2 \mathrm{hr}$ before restraint stress and immediate indomethacin administration in a dose of $100 \mathrm{mg} / \mathrm{kg}$ (i.p). Histopathological examination showed (i) Partial preservation of the mucus layer (red arrow), (ii) Deep mucosal ulcer not penetrating the submucosa (black arrow), (iii) Moderate submucosal oedema (blue arrow) (H\&E x235).

Figure (6): Rats received Hyoscine N-butylbromide in a dose of $1 \mathrm{mg} / \mathrm{kg}$ (i.p) $1 / 2 \mathrm{hr}$ before restraint stress and immediate indomethacin administration in a dose of $100 \mathrm{mg} / \mathrm{kg}$ (i.p). Histopathological examination showed: (i) Scattered parietal cells (blue arrow), and (ii) Marked dilated congested submucosal blood vessels (black arrow) (H\&E x360).
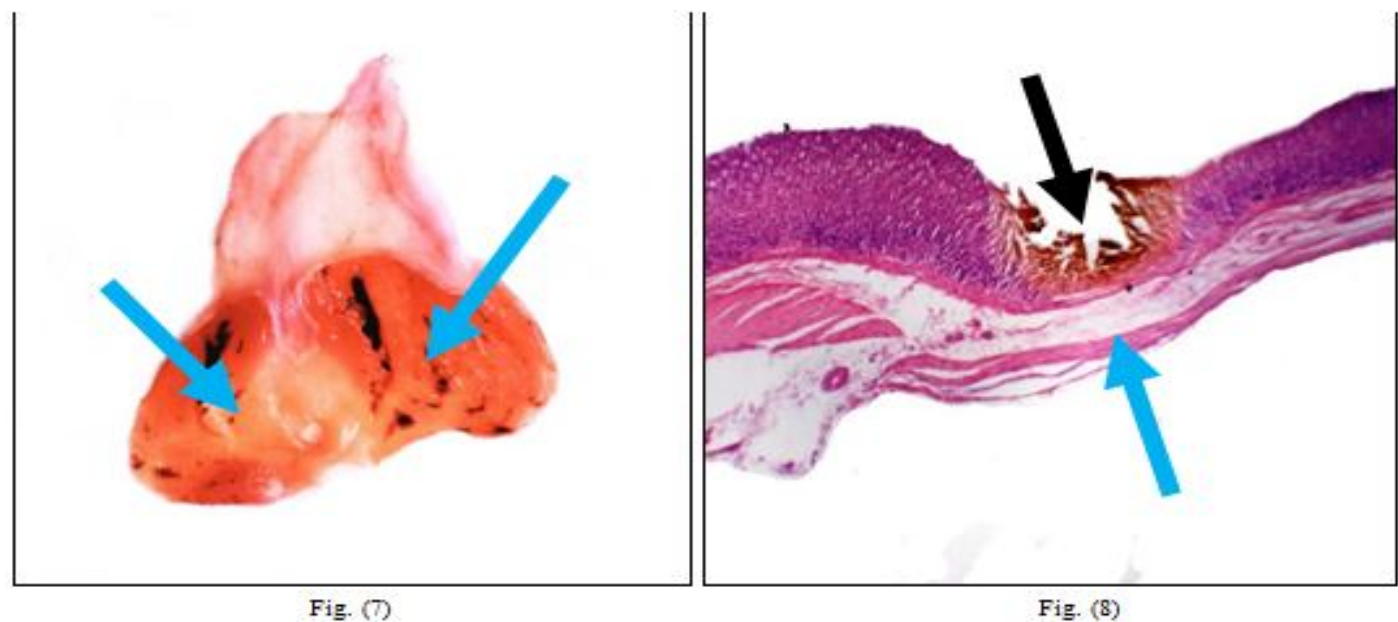

Figure (7): Rats received Hyoscine N-butylbromide in a dose of $2.5 \mathrm{mg} / \mathrm{kg}$ (i.p) $1 / 2 \mathrm{hr}$ before restraint stress and immediate indomethacin administration in a dose of $100 \mathrm{mg} / \mathrm{kg}$ (i.p). Naked eye examination showed multiple ulcers in each corpus of the stomach (blue arrow).

Figure (8): Rats received Hyoscine N-butylbromide in a dose of $2.5 \mathrm{mg} / \mathrm{kg}$ (i.p) $1 / 2 \mathrm{hr}$ before restraint stress and immediate indomethacin administration in a dose of $100 \mathrm{mg} / \mathrm{kg}$ (i.p). Histopathological examination showed: (i) Deep ulcers involving the whole mucosal thickness and lined by granulation tissue (black arrow), (ii) Mild submucosal oedema (blue arrow) (H\&E\& x150). 


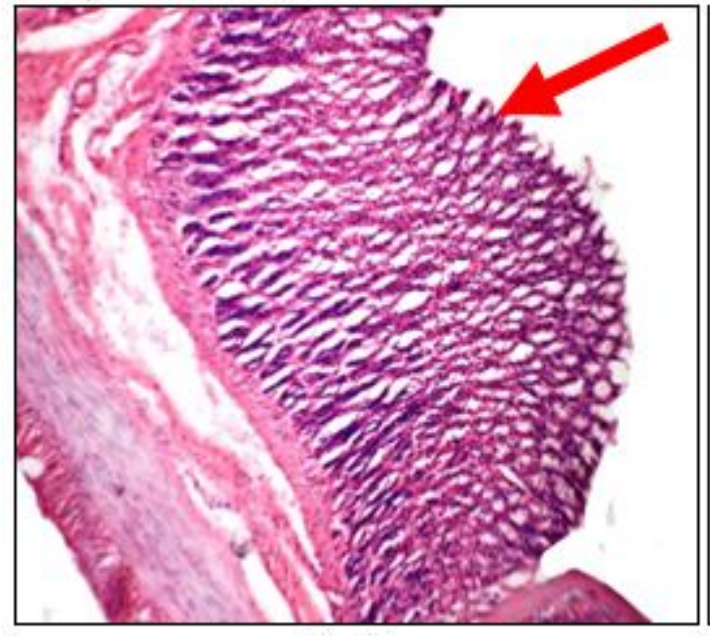

Fig. (9)

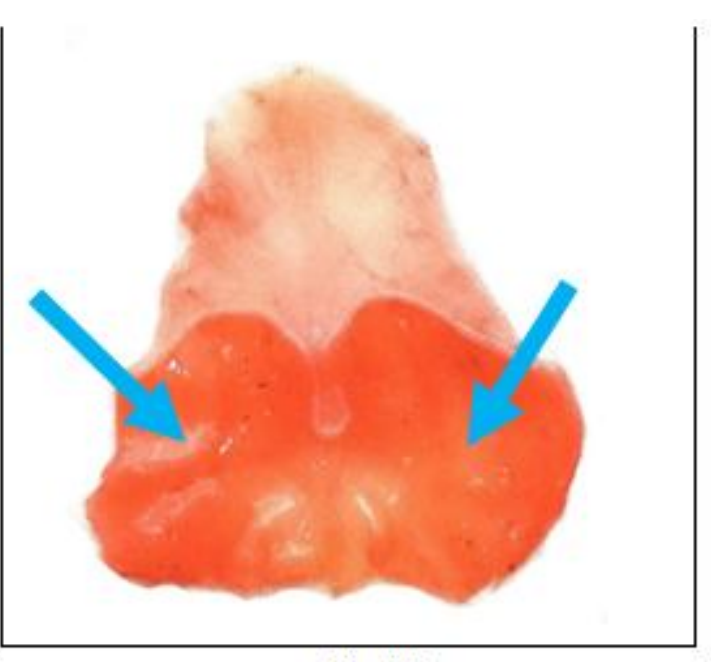

Fig. (10)

Figure (9): Rats received Hyoscine N-butylbromide in a dose of $2.5 \mathrm{mg} / \mathrm{kg}$ (i.p) $1 / 2 \mathrm{hr}$ before restraint stress and immediate indomethacin administration in a dose of $100 \mathrm{mg} / \mathrm{kg}$ (i.p). Histopathological examination showed partial loss of superficial mucus layer (red arrow) (H\&E x235).

Figure (10): Rats received Hyoscine N-butylbromide in a dose of $5 \mathrm{mg} / \mathrm{kg}$ (i.p) $1 / 2 \mathrm{hr}$ before restraint stress and immediate indomethacin administration in a dose of $100 \mathrm{mg} / \mathrm{kg}$ (i.p). Naked eye examination showed very few superficial gastric mucosal ulcers (blue arrow).

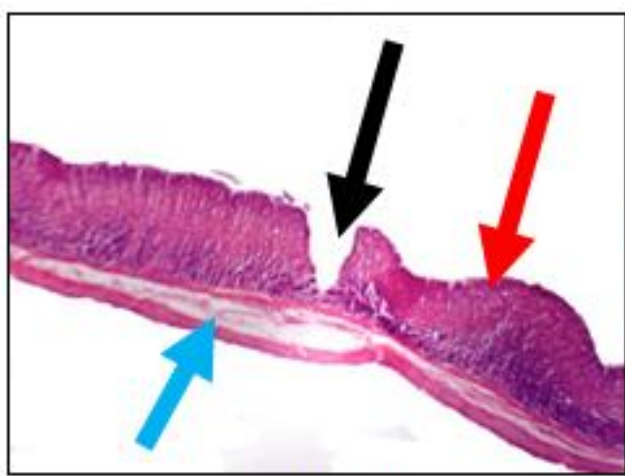

Fig. (11)

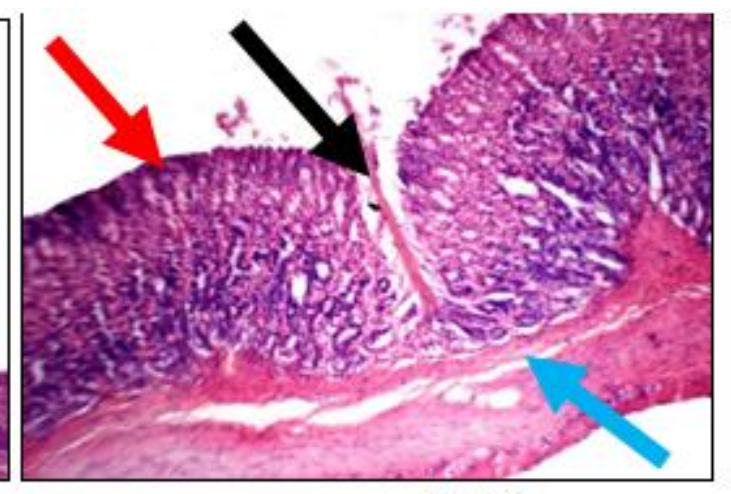

Fig. (12)

Figure (11): Rats received Hyoscine N-butylbromide in a dose of $5 \mathrm{mg} / \mathrm{kg}$ (i.p) 1/2hr before restraint stress and immediate indomethacin administration in a dose of 100mg/kg (i.p). Histopathological examination showed: (i) Gastric mucosal ulcers not penetrating the deep epithelial layer (black arrow), (ii) Preservation of the mucus layer (red arrow), (iii) Very mild submucosal oedema (blue arrow) (H\&E x150).

Figure (12): Rats received Hyoscine N-butylbromide in a dose of $5 \mathrm{mg} / \mathrm{kg}$ (i.p) 1/2hr before restraint stress and immediate indomethacin administration in a dose of 100mg/kg (i.p). Histopathological examination showed: (i) Narrow gastric mucosal ulcers not penetrating the deep epithelial layer (black arrow), (ii) Preservation of the mucus layer (red arrow), (iii) No submucosal oedema (blue arrow) (H\&E x235). 
Studies on Gastric secretions:

A- Effect of different doses of HBB $(1 \mathrm{mg} / \mathrm{kg}, 2.5 \mathrm{mg} / \mathrm{kg}$, and $5 \mathrm{mg} / \mathrm{kg})$ on gastric secretion in pyloric ligated rats received indomethacin i.p in a dose of 100 mg/Kg. (Figures 13, 14, 15).

-Effect of saline administration in a dose $1 \mathrm{~mL}$ (i.p)/rat on gastric secretion in pyloric ligated rats (control group).

- The mean volume of the gastric juice $(2.4000 \pm 0.05164 \mathrm{~mL})$.

- The mean titritable acidity (14.0000 $\pm 0.25820 \mathrm{mEq} / \mathrm{L}$ ).

- The mean total acid output $(0.0336$ \pm 0.00082 micro equivalent $/ 3 \mathrm{hrs}$ ).

B- Effect of indomethacin administration (i.p) in a dose of 100 $\mathrm{mg} / \mathrm{Kg}$ on gastric secretion in pyloric ligated rats.

- A non-significant decrease in the mean volume of the gastric juice $(2.2833 \pm 0.04014 \mathrm{~mL})$ as compared to the control group received saline $(2.4000 \pm 0.05164 \mathrm{~mL})$.

- A significant decrease in the mean titritable acidity $(7.0000 \pm 0.44721$ $\mathrm{mEq} / \mathrm{L}$ ) as compared to the control group received saline (14.0000 $\pm 0.25820 \mathrm{mEq} / \mathrm{L})$.

- A significant decrease in the mean total acid output $(0.0159 \pm 0.00077$ micro equivalent $/ 3 \mathrm{hrs}$ ) as compared to the control group received saline $(0.0336 \pm 0.00082$ micro equivalent $/ 3$ hrs).

C- Effect of (i.p) administration of HBB (i.p) in a dose of $1 \mathrm{mg} / \mathrm{Kg} 1 / 2 \mathrm{~h}$ before pyloric ligation and indomethacin administration :

- A significant decrease in the mean volume of the gastric juice (1.4000 \pm $0.02582 \mathrm{~mL}$ ) as compared to the group received indomethacin only $(2.2833 \pm$ $0.04014 \mathrm{~mL}$ ).
- A significant decrease in the mean titritable acidity $(4.0000 \quad \pm 0.00000$ $\mathrm{mEq} / \mathrm{L}$ ) as compared to the group received indomethacin only $(7.0000 \pm$ $0.44721 \mathrm{mEq} / \mathrm{L}$ ).

- A significant decrease in the mean total acid output $(0.0056 \pm 0.00010$ micro equivalent $/ 3 \mathrm{hrs}$ ) as compared to the group received indomethacin only $(0.0159 \pm 0.00077$ microequivalent $/ 3$ hrs).

D- Effect of (i.p) administration of HBB (i.p) in a dose of $2.5 \mathrm{mg} / \mathrm{Kg} 1 / 2 \mathrm{~h}$ before pyloric ligation and indomethacin administration :

- A significant decrease in the mean volume of the gastric juice $(1.2000 \pm$ $0.04472 \mathrm{~mL}$ ) as compared to the group received indomethacin $(2.2833 \pm$ $0.04014 \mathrm{~mL}$ ).

- A significant decrease in the mean titritable acidity $(3.3333 \pm 0.14926$ $\mathrm{mEq} / \mathrm{L}$ ) as compared to the group received indomethacin $(7.0000 \pm$ $0.44721 \mathrm{mEq} / \mathrm{L}$ ).

- A significant decrease in the mean total acid output $(0.0040 \pm 0.00026$ micro equivalent $/ 3 \mathrm{hrs}$ ) as compared to the group received indomethacin $(0.0159 \pm 0.00077$ micro equivalent $/ 3$ hrs).

Effect of (i.p) administration of HBB (i.p) in a dose of $5 \mathrm{mg} / \mathrm{Kg} 1 / 2 \mathrm{~h}$ before pyloric ligation and indomethacin administration :

- A significant decrease in the mean volume of the gastric juice (1.1667 \pm $0.06146 \mathrm{~mL}$ ) as compared to the group received indomethacin (2.2833 \pm $0.04014 \mathrm{~mL}$ ).

- A significant decrease in the mean titritable acidity (3.3333 \pm 0.16667 $\mathrm{mEq} / \mathrm{L}$ ) as compared to the group received indomethacin $(7.0000 \pm$ $0.44721 \mathrm{mEq} / \mathrm{L})$. 


\section{Mohamed Samy El-Ficky et al.}

- A significant decrease in the mean total acid output $(0.0038 \pm 0.00009$ micro equivalent $/ 3 \mathrm{hrs}$ ) as compared to

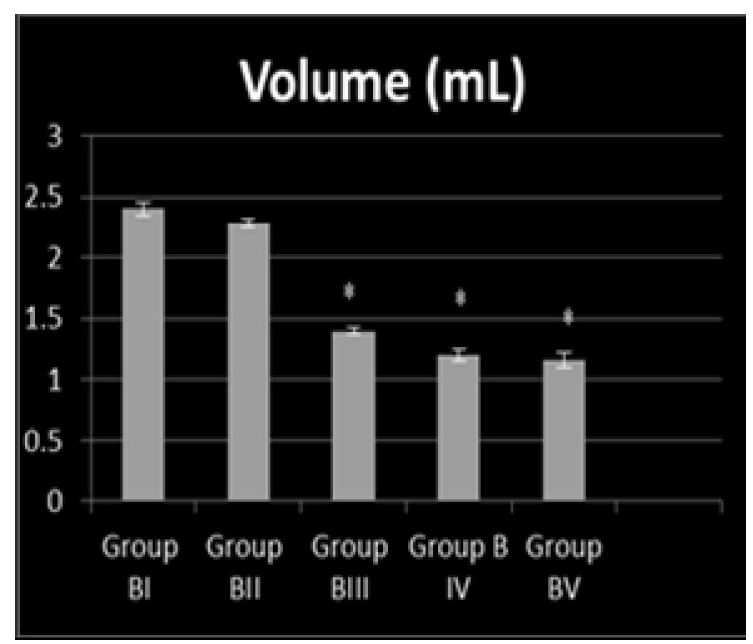

the group received indomethacin $(0.0159 \pm 0.00077$ micro equivalent $/ 3$ hrs).

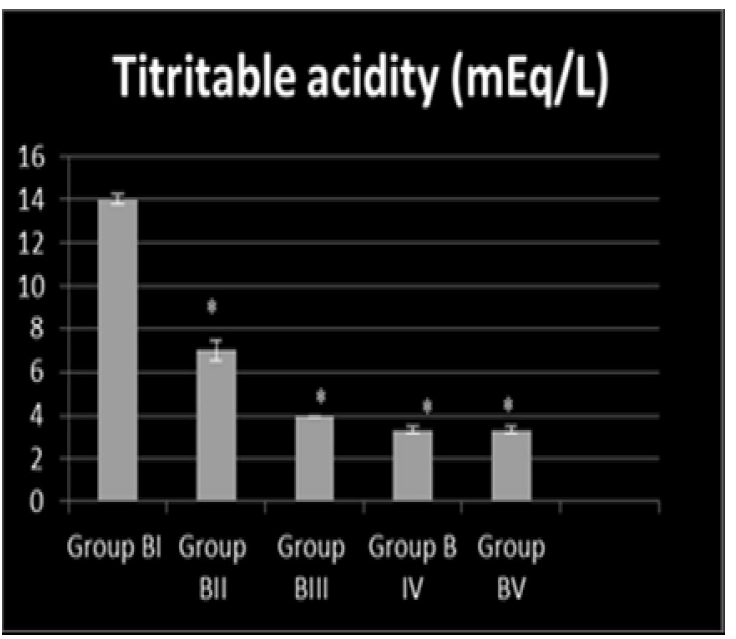

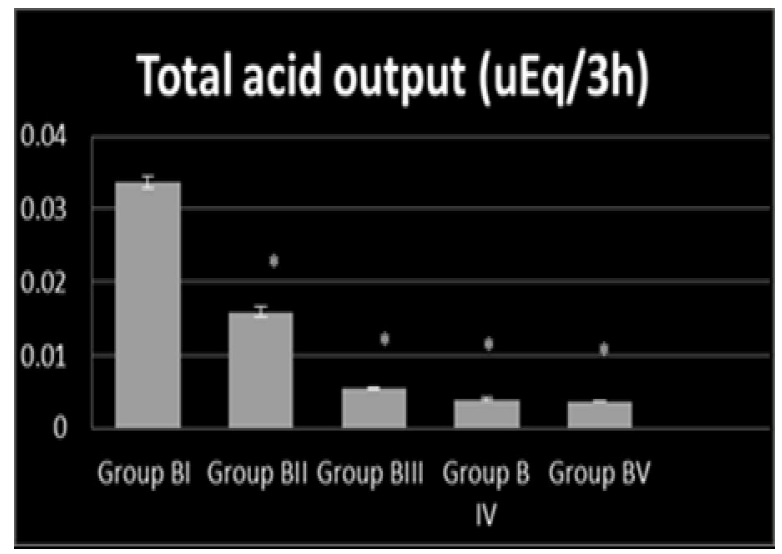

Fig (13)

Fig (14) 


\section{EFFECT OF HYOSCIN N-BUTYL BROMIDE}

Figure (13): Effects of (i.p) administration of various doses of $\mathrm{HBB}$ (1, 2.5 and 5 $\mathrm{mg} / \mathrm{kg}$ ) on the mean volume of gastric juice in pyloric ligated rats received indomethacin in a dose of $100 \mathrm{mg} / \mathrm{kg}$.

Figure (14): Effects of (i.p) administration of various doses of $\mathrm{HBB}$ (1, 2.5 and 5 $\mathrm{mg} / \mathrm{kg}$ ) on titritable acidity in pyloric ligated rats received indomethacin in a dose of $100 \mathrm{mg} / \mathrm{kg}$.

Figure (15): Effects of (i.p) administration of various doses of HBB (1, 2.5 and 5 $\mathrm{mg} / \mathrm{kg}$ ) on total acid output in pyloric ligated rats received indomethacin in a dose of $100 \mathrm{mg} / \mathrm{kg}$.

Group BI: Rats received saline i.p. in a dose of $1 \mathrm{~mL} /$ rat immediately before pyloric ligation.

Group BII: Rats received indomethacin in a dose of $100 \mathrm{mg} / \mathrm{Kg}$ (i.p) immediately before pyloric ligation.

Group BIII: Rats received HBB i.p. in a dose of $1 \mathrm{mg} / \mathrm{Kg}, 1 / 2 \mathrm{~h}$ before indomethacin administration (i.p) and pyloric ligation.

Group BIV: Rats received HBB i.p. in a dose of $2.5 \mathrm{mg} / \mathrm{Kg}, \quad 1 / 2 \quad \mathrm{~h}$ before

\section{DISCUSSION}

Our results showed that indomethacin administration in a dose of $100 \mathrm{mg} / \mathrm{kg}$ (i.p) to pyloric ligated rats led to a nonsignificant decrease in gastric juice volume as compared to the control group. Our results are in contradictory to the result of (Naito et al., 2008), who reported a marked reduction in gastric blood flow produced by drugs was accompanied by reduction of the volume of gastric secretion, but (Biplab et al., 2011) and (Muhammed et al., 2012), reported that indomethacin have caused alternation in gastric secretions of rats.

Our results showed that indomethacin administration in a dose of $100 \mathrm{mg} / \mathrm{kg}$ (i.p) to pyloric ligated rats led to a significant decrease in gastric acid concentration and indomethacin administration (i.p) and pyloric ligation.

Group BV: Rats received HBB i.p. in a dose of $5 \mathrm{mg} / \mathrm{Kg}, 1 / 2 \mathrm{~h}$ before indomethacin administration (i.p) and pyloric ligation.

Group BII was compared to the control group BI. Groups BIII, BIV, and Group BV were compared to Groups BII.

gastric acid output as compared to the control group received saline (i.p). Our results are in controversy to the results of (Filaretova et al., 2002), whom reported an increased gastric acid secretion in the occurrence of sever indomethacin induced stomach damage.

In our results, the decrease in gastric acid concentration, and gastric acid output induced by indomethacin administration was most probably due to a decrease in gastric blood flow (Muhammed et al., 2012), the direct toxic effect on the oxyntic cells, induction of apoptosis and inhibition in epithelial cell proliferation in the ulcer margin (Beck et al., 2000).

Our results showed that pretreatment by Hyoscin N-butylbromide in doses of $1 \mathrm{mg} / \mathrm{kg}, 2.5 \mathrm{mg} / \mathrm{kg}$ and $5 \mathrm{mg} / \mathrm{kg}$ (i.p) to pyloric ligated rats received indomethacin 


\section{Mohamed Samy El-Ficky et al.}

in a dose of $100 \mathrm{mg} / \mathrm{kg}$ (i.p) led to a significant decrease in gastric acid concentration and gastric acid output as compared to the group-received indomethacin only.

Our results showed that pretreatment by Hyoscin N-butylbromide in doses of $(1 \mathrm{mg} / \mathrm{kg}, 2.5 \mathrm{mg} / \mathrm{kg}$ and $5 \mathrm{mg} / \mathrm{kg}$ ) (i.p) to groups of rats subjected to restraint stress and indomethacin administration in a dose of $100 \mathrm{mg} / \mathrm{kg}$ (i.p) led to a decrease in the ulcer index as compared to group of rats subjected to restraint stress and received indomethacin only with a protection ratio of $3 \%, 60.5 \%$ and $66.4 \%$ respectively .

Our results support the concept that most of the anti-ulcer drugs presently used as anticholinergic and anti-acid drugs are produced with the aim of reducing gastric acid secretion, and treatment of gastric ulcer by anticholinergic drugs as a result of gastric acid inhibition can be exemplified (Zanatta et al., 2009; and Suleyman et al., 2010).

The parasympathetic blocker pirenzepine are used for the treatment of gastric ulcer and as a gastroprotective drug acting on offensive factors interfere with acid secretion (Mahmood et al., 2010 and Saravanan et al., 2011). Propanthocyanidine extracts of the black grape seeds (vitis vinifera), has a prophylactic effects against indomethacin - induced gastric ulceration in rabbits due to its anti-secretory activity (significant increase in gastric $\mathrm{pH}$, a decrease in gastric juice volume, and total gastric acidity (Anamad et al., 2014; Ingale et al., 2014 and Abdul-Razek et al., 2015).

Our results are also in concomitant with the results of (Abdul-Razek et al., 2015), whom reported that propanthocyanidine extracts of the black grape seeds (vitis vinifera), has a prophylactic effects against indomethacin - induced gastric ulceration due to its antisecretory activity.

Hyoscin N-butylbromide clearly antagonized muscarinic receptor induced activation of the muscle, the epithelium and enteric neurones, and significantly reduced bethanecol-induced action potential in enteric neurones (Krueger et al., 2013). Hyoscin N-butylbromide obviously reaches its target structures, i.e. muscarinic receptors of smooth muscle cells, parasympathetic ganglia, and / or possibly nicotinic receptors on enteric neurones (Weiser and Just, 2009). Peripheral anticholinergic effects of Hyoscin N-butylbromide results from a ganglion - blocking action within the visceral wall, as well as from antimuscarinic activity (Samuels, 2009; and Krueger et al., 2013).

Stomach ulceration reduced the gastric mucin content (Adhikary et al., 2011). This might reduce the ability of the mucosal membrane to protect the mucosa from physical damage and back diffusion of hydrogen ions, and hinder epithetical recovery (Adhikary et al., 2011). Inhibition of PGs caused decrease in mucin secretion then allows hydrogen ions and pepsin to diffuse into the mucosa from the lumen. So, back diffusion of acid and pepsin into the tissue stimulate more acid and pepsin secretion to cause more damage (Abdallah et al., 2011). It is difficult to attribute the gastro toxic effects of indomethacin to only one factor, specially the inhibition of COX -1 (Suleyman et al., 2010). 


\section{EFFECT OF HYOSCIN N-BUTYL BROMIDE}

By histopathologicl examination, our results showed (Figures 1, 2, 3) deep ulcers reaching the submucosal layer with loss of the superficial mucus in rats subjected to restraint stress and indomethacin administration.

(Suleyman et al., 2010) reported that the relationship between the increase of mucus secretion and gastroprotection is not considerable. But treatment with Black Tea (BT) and Thea - flavins (Tf) significantly accelerated ulcer healing, which was associated with an increase in the mucin content of the gastric mucosa. The test samples BT and Tf, restored the mucin level to normalcy (Adhikary et al., 2011).

Our results showed that pretreatment by Hyoscin N-butylbromide in doses of $1 \mathrm{mg} / \mathrm{kg}, \quad 2.5 \mathrm{mg} / \mathrm{kg}$ (i.p) $1 / 2 \mathrm{hr}$ before restraint stress and indomethacin administration led to a partial preservation of the mucus layer lining the stomach, and pretreatment by Hyoscin N-butylbromide in a dose of $5 \mathrm{mg} / \mathrm{kg}$ (i.p) $1 / 2 \mathrm{hr}$ before restraint stress and indomethacin administration led to complete preservation of the mucus layer lining the stomach.

Our results are in concomitant with the results of (Adhikary et al., 2011), whom reported that preservation of the mucus content of the gastric mucosa has a prophylactic effect against both restraint and indomethacin - induced gastric ulcers .

Acetylcholine is one of the most important neurotransmitters in the gut, since the vagus nerve and the sacral parasympathetic nerve, as well as the cholinergic entire neurones, play a key role in regulation gastrointestinal motility (Auli et al., 2008; O'Donnell and Puri,
2009). Muscarinic M2 and M3 receptor were the muscarinic cholinergic subtypes distributed in the gut wall (Tobin et al., 2009), especially in the circular and longitudinal muscular layer, which contributed to the regulation of gastrointestinal motility (Harrington et al., 2010). The inhibitory effects of Buscopan were mainly responsible for the antagonism of muscarinic M2 and M3 receptors (Zhang et al., 2016). It is relatively less effective on the stomach than intestine (Ge et al., 2011; and Papadopoulos et al., 2014). Hyoscine Nbutylbromide (HBB) block the action of acetylcholine at parasympathetic sites (both muscarinic and nicotinic receptors) in smooth muscle, and in secretory glands, it causes decreased motility of the gastrointestinal tract (Zhang et al., 2016).

\section{CONCLUSION}

Intraperitoneal administration of $\mathrm{HBB}$ in doses of $1 \mathrm{mg} / \mathrm{Kg}, \quad 2.5 \mathrm{mg} / \mathrm{Kg}$ and $5 \mathrm{mg} / \mathrm{Kg}$, to rats in a dose-dependent manner led to a prophylactic effect against stress induced gastric ulcers with a protection ratio $(3 \%, 60.46 \%$ and $66.41 \%)$ respectively.

\section{REFERENCES}

1. Abdallah I, Khattab H and Heebab G (2011): Gastroprotective effect of CordiaMyxa L. fruit extract against indomethacin-Induced Gastric Ulceration in Rats. Life Sci. J., 8(3): 433-445.

2. Abdul -Razek AS, Mona H, AL-Saeed Eman A and AL-Masoudi A (2015): The Anti-Ulcer and Anti-Hypothyroidism Effects of Propanthocyanidine and Ranitidine in Female Rabbits with Gastric Ulceration Induced by Indomethacin. Indian J. of Applied Research, 5(11): 2249-555X.

3. Adhikary B, Yadav S.K, Royk, Bandyopadhyay S.K. and Chatlopadhyay S (2011): Black tea and the aflavins Assist 


\section{Mohamed Samy El-Ficky et al.}

Healing of indomethacin induced Gastric ulceration in Mice by Ant oxidative Action. Evidence-Based complementary and Alternative Medicine Article, 546560: 1-11.

4. Anand $M$, Rajendran V, and Pinnelli B (2014): Experimental evaluation of the antiulcer activity of grape (vitis vinifera) seed extract in Wister albino rats. Int. J. App. Bio. Pharm. Tech., 5 :(4).

5. Anchkov, S.V and Zovodskoya, I.S (1968): The experimental Basis of gastric ulcer pharmacotherapy, p.56. Pbl. Pergamon press.

6. Auli, M., Martinez, E., Gallego, D., Opazo, A., Esp?n, F., Mart? Gallostra, M., Jiménez, M. and Calve, P. (2008): Effects of excitatory and inhibitory neurotransmission on motor patterns of human sigmoid colon in vitro. Br. J. Pharmacol., 155: 1043-1055.

7. Beck, P.L. Xavier, R.; Lu, N. Nanda, N.N. Dinauer, M. and Podolsky, D.K. (2000): Mechanisms of NSAID-induced gastrointestinal injury defined using mutant mice, Gastroenterology, 119 (3): 699-705.

8. Berenguer, B., L.M. Sanchez, A. Quilea, M. Lopez-Barreiro, O. De Haro, J. Galvez and Martin M.J. (2006): Protective and antioxidant effects of Rhizophora mangle it mangle L. Against NSAID-induced gastric ulcers. J. Ethanopharmacol., 77: 1-3.

9. Biplab A, Sudhir K.Y, Kshama R, SandipK B and Subrata C. (2011): Black tea and the aflavins assist healing of indomethacin-induced gastric ulceration in mice by antioxidative action, Evid Based Complem Alt Med., 11:1122.

10. Brodie, D.A and Hooke, K.F. (1971): The effect of vasoactive agents on stress - induced gastric haemorrhage in the rat. Digestion, 4: $193-204$.

11. Cuparencu B. and Sandor V (1977): Influence of some sympathomimetic Amines on the Experiment Gastric ulcers in Rats. Pharmacology, 15: 218-226.

12. Drury, R.A.B and Wallington, F.A. (1980): Carleton's Histological technique, fifth edition, Oxford University Press. Oxford, New York, Toronto.
13. Filaretova, L., Tanaka, A. Miyazawa, T. Kato, S. and Takeuchi. K. (2002): Mechanisms by which endogenous glucocorticoid protects against indomethacininduced gastric injury in rats. American Journal of Physiology Gastrointestinal and Liver Physiology, 283: G1082-G1089.

14. Ge, Z., Yuan, Y., Zhang, S., Hou, X., Wang, J., Cai, J., Shi, R., Li, Y., Wang, B., Ji, F., Richter, E. and Schaefer, E. (2011): Efficacy and tolerability of two oral hyoscine Butylbromide for mulationsin Chinese patients with recurrent episodes of self- Reported gastricorintestinal spasm-like pain. Int. J. Clin. Pharmacol. Ther., 49: 198-205.

15. Grossman, M.I. (1963): Gastric secretion in Physiology for the Physicians. A monthly publication of American physiological Society, 1(7): $1-5$.

16. Harrington AM, Peck CJ, Liu L, Burcher E, Hutson JM and Southwell BR. (2010): Localization of muscarinic receptors M1R, $\mathrm{M} 2 \mathrm{R}$ and M3R in the human colon. Neurogastroenterol Motil., 22: 999-1008.

17. Ingale Anand. M., Rajendran and Venkata B. P. (2014): A Comparative Evaluation of the Anti-Ulcer Activity of the Extracts of Seed and Skin of Vitis Vinifera. Intl. J Clin. Diag. Res., 2: $2: 1$

18. Jansson EA., Petersson J., Reinders C., Solikot. Bjosin H. and Phillipson M. (2007): Protection from nonsteroidal anti-inflammatory drug (NSAID) - Induced gastric ulcers by dietary nitrate, Free Radical Biology \& Medicine, 42: 510-518.

19. Kasuya $Y$, Urushidani $T$ and Okabe $S$ (1978): Effects of various drugs and vagotomy on indomethacin-induced gastric ulcers in the rat. Jpn. J Pharmacol, 29: 670-673.

20. Krueger D, Zeller F, Langer R, Demir IE, Ceyhan GO and Schemann M (2013): Effect of hyoscine butylbromide (Buscopan ${ }^{\circledR}$ ) on cholinergic pathways in the human intestine. Neurogastroenterol Motil., 25: e530-e539.

21. Lacy BE, Wang F, Bhowal S and Schaefer E (2013): On-demand hyoscine butylbromide for the treatment of self-reported functional 


\section{EFFECT OF HYOSCIN N-BUTYL BROMIDE}

cramping abdominal pain. Scandinavian Journal of Gastroenterology, 48(8):926-35.

22. Mahmood, A.A.; Abdalbasti, A.M.; Al Bayaty, F. and Ibrahim, S. (2010): Anti ulcerogenic activity of Gynuraprocum bens leaf extract against experimentally induced gastric ulcer lesion in rats. J Med plant Res., 4: 271275.

23. Muhammed, A.V.K. G., Thamotharan, S., Sengottuvelu, S. and Haja-Sherief, T. S. (2012): Evaluation of antiulcer activity of Ficuspumila L. leaf extract in albino rats, Glob J Res Med Plants Indig Med., 1(8).

24. Naito $\mathbf{Y}$, Iinuma $S$, Yagi $\mathbf{N}$, Boku $\mathbf{Y}$, Imamoto E, Takagi T. (2008): Prevention of indomethacin-induced gastric mucosal injury in Helicobacter pylori-Negative Healthy volunteers: A comparison study Rebamipide vs Famotidine. J Clin Biochem Nutr., 43: 34-40.

25. O'Donnell, A.M. and Puri, P. (2009): Cholinergic innervation in the developing chick cloaca and colorectal. J. Pediatr. Surg., 44: 392-394.

26. Okabe, S., Honda, K., Takeuchi, K. and Takagi, K. (1975): Inhibitory effect of Lglutamine on gastric irritation and back diffusion of gastric acid in response to aspirin in the rat. Am. J. Dig. Dis., 20(7): 626-31.

27. Papadopoulos, G., Bourdoumis, A., Kachrilas, S., Bach, C., Buchholz, N. and Masood, J. (2014): Hyoscine-butylbromide (Buscopan) in the treatment of acute ureteral colic: what is the evidence? Urol. Int.; 92: 253257.

28. Ruepert L, Quartero AO, de Wit NJ, van der Heijden GJ, Rubin G and Muris JW (2011): Bulking agents, antispasmodics and antidepressants for the treatment of irritable bowel syndrome. The Cochrane Database Syst Rev., 10(8): 3460-3466.

29. Samuels LA (2009): Hyoscine butylbromide in the treatment of abdominal spasms. Clinical Medicine: Therapeutics, 1: 647-655.

30. Saravanan, J.; Venkatesh, P.; Soumya, V.; Hariprasath, K.; Prasad, R.H. and Kumar, K.T.M. (2011): Antiulcer and antioxidant activity of methanolic leaf extract of Soymida Febrifuga. J Pharm Res., 5:528-531.
31. Shay, H; Sun, D.C.H. and Gruenstein, $M$ (1954): A quantitative method for measuring spontaneous gastric secretion in the rat. Gastroenterology, 26: 906 - 913.

32. Suleyman, H., Albayra KA., Bilici M., Cadirici E. and Halici Z (2010): Different mechanisms in formation and prevention of indomethacin-induced Gastric ulcers. Inflammation, 33(4): 224-234.

33. Tobin, G., Giglio, D. and Lundgren, $O$. (2009): Muscarinic receptor subtypes in the alimentary tract. J. Physiol. Pharmacol., 60: 321

34. Tytgat GN (2008): Hyoscine butylbromide-a review on its parenteral use in acute abdominal spasm and as an aid in abdominal diagnostic and therapeutic procedures. Current Medical Research and Opinion, 24(11): 3159-3173.

35. Weiser T and Just S. (2009): Hyoscine butylbromide potently blocks human nicotinic acetylcholine receptors in SH-SY5Y cells. Neurosci Lett., 450: 258-261.

36. Whittaker C (2010): Over-the-counter medicines for infants: mother and child health. Professional Nursing Today, 14(6):18-22.

37. Zanatta, F., Gandol?, R.B. Lemos, M. Ticona, J.C. Gimenez, A. and Clasen B. K. (2009): Gastroprotective activity of alkaloid extract and 2-phenylquinoline obtained from the bark of Galipea longi?ora Krause (Rutaceae). Chemico - Biological Interactions, 180: 312-317.

38. Zhang Lei, Jun Song, Tao Bai, Xiaoming Lu, Guanghai Yang, Wei Qian, Ruiyun Wang and Xiaohua Hou (2016): Effects of Buscopan on human gastrointestinal smooth muscle activity in an ex vivo model: Are there any differences for various sections. European Journal of Pharmacology, 780: 180-187. 


\section{Mohamed Samy El-Ficky et al.}

در اسة تأثير عقار الهيوسين ن-بيوتيل بروميد على قرحة

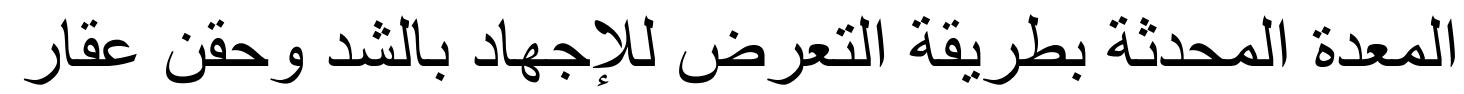

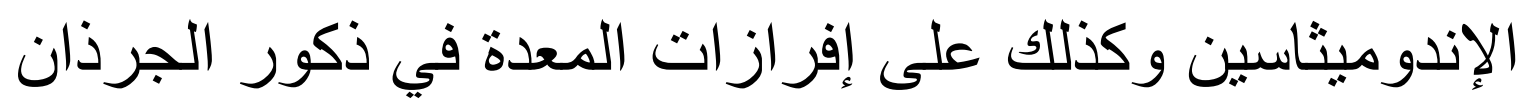
البيضاء البالغة إنة

محمد سامي الفقي ـ محمد أبو الحسن زعير - سيد عبد الرحيم سيد* - و ائل أحمد خطاب

قسمي الفسيولوجيا الطبية والباثولوجيا* ـكلية طب الأزهر

خلفيـة البحث : يستخدم عقار الهيوسين ن-بيوتيل بروميد كمضـاد لإفراز الكولين ومضـاد للتقلصـات لعلاج النقلصات المعوية او آلام الأمعاء المصحوبة بائة بالتقلصات.

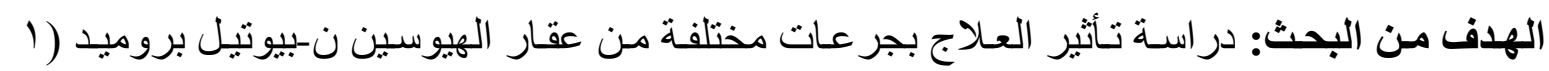

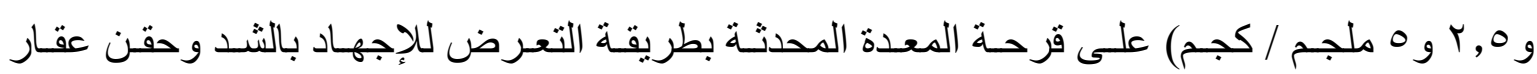
الاندوميثاسين وكذلك على إفرازات المعدة في ذكور الجرذان البيضاء البالغة.

مواد وطرق البحث: إستخدم في هذا البحث ستون من ذكور الجرذان البيضـاء وقد تم تقسيم الجرذان إلى قسمين متساويين. وقد تم تقسيم كلا من القسميين الكبيرين الي أقسام خمسة منساوية.

النتائج: إعطاء عقار الهيوسين ن-بيوتيل بروميد بجر عة ( الجم / كجم) عن طريق الحقن الصفاقي

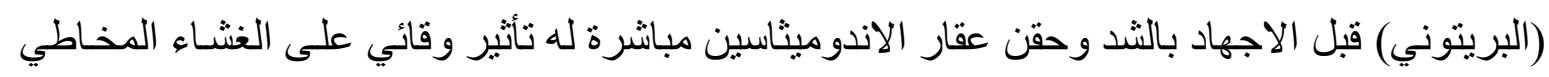

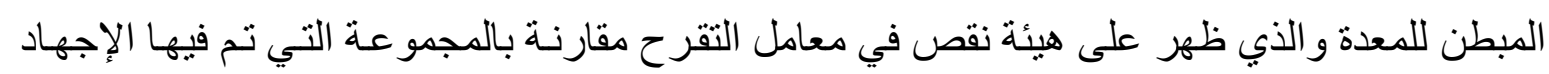

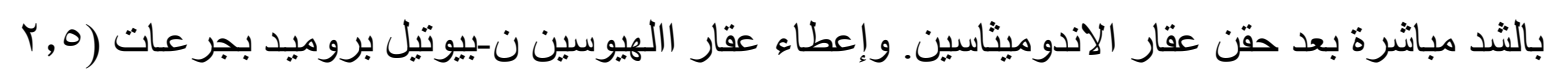

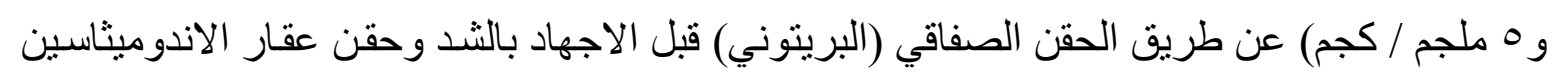

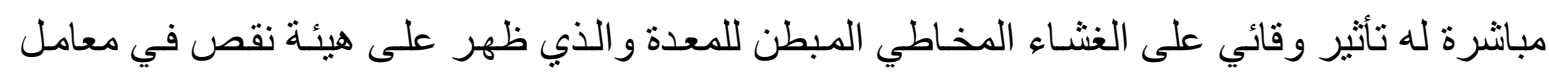

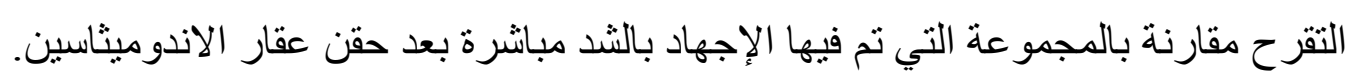

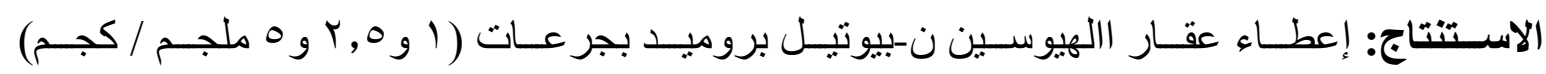

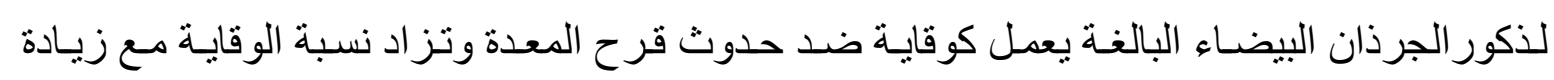

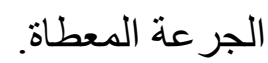

